\title{
Jovellanos: La reconstrucción de un clásico
}

\author{
JOAQUín OCAMPO SUÁREZ-VALDÉS \\ Universidad de Oviedo, Facultad CC.EE., Campus del Cristo, Avda. del Cristo, s/n, 33006 Oviedo, \\ España. E.-mail: jocampo.uniovi.es
}

\begin{abstract}
«Las obras valiosas logran sobreponerse a los sucesivos lectores, editores, traductores y exégetas, sin perecer en la prueba.[...], y Jovellanos hace tiempo que ha adquirido la categoría de clásico de la Ilustración española. Quizá la disparidad de juicios haya sido, y siga siendo, el precio a pagar por alcanzar tal categoría (V. Llombart $\left.{ }^{1}\right)$.
\end{abstract}

\section{RESUMEN}

Hasta el año 2012, la bibliografia jovellanista sumaba algo más de 3.900 referencias, indicador del éxito editorial pero también del riesgo de que los intérpretes de Jovellanos, de seguir incrementándose, lleguen a superar algún día a sus propios lectores. Indudablemente, dentro de tal vorágine bibliográfica, abundan toda clase de usos, abusos y distorsiones, que no dejan de ser parte del lastre que persigue a cualquier autor que haya alcanzado la condición de «clásico». En este artículo se trata de explicar tanto la facilidad de esa proliferación de usos y abusos de «jovellanismo», como de remitirla a los contextos históricos específicos que la alimentan.

Palabras clave: Jovellanos, jovellanismo, representaciones, interpretaciones, usos, abusos.

\section{Jovellanos: The Reconstruction of a Classic}

\begin{abstract}
Until 2012, the amount of bibliographic references on Jovellanos amounted to a number of 3,900, which is an indication of publishing success. However, this considerable amount also indicates the risk that, if the number of specialists on Jovellanos continues to increase, it will become larger than the number of his readers. Undoubtedly, within this bibliographic confusion, all kinds of uses, overuses and distortions can be found, and this is nothing but the burden that is usually attached to every author that has achieved the category of "classic". This article attempts to explain how easily the amount of uses and overuses has increased, as well as how this proliferation should be placed in historical contexts that have fostered it.
\end{abstract}

Keywords: Jovellanos, “Jovellanism”, Representations, Uses, Overuses.

Clasificación JEL: A11, A14, B00, B31

\footnotetext{
${ }^{1}$ Llombart (2013), pp. 207 y 209.
}

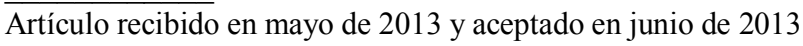

Artículo disponible en versión electrónica en la página www.revista-eea.net, ref. ə-32102 


\section{INTRODUCCIÓN}

De otorgar a google algún reconocimiento como indicador de visibilidad social, Jovellanos, con 3.480.000 «entradas», sería el economista de la ilustración española con mayor presencia en la red. Hay, obviamente, indicadores más fiables. A finales de 2012, la bibliografía jovellanista recogía hasta 3.902 referencias sobre el ilustrado asturiano ${ }^{2}$. Jovellanos, además, ha prestado su nombre dentro y fuera de Asturias a calles y plazas, parques y jardines, sociedades recreativas, logias masónicas, ateneos, instituciones culturales y educativas, municipios -Jovellanos (Matanzas, Cuba)-, a especies florales ${ }^{3}$-la Jovellana punctata o «caprichito morado»-, entre otras-... Su imagen ha iluminado oleos, grabados, monedas, sellos y billetes de lotería, además de bustos y toda clase de monumentos conmemorativos. A escala regional no es exagerado señalar que Jovellanos, junto a don Pelayo y la virgen de Covadonga, integra la trilogía de deidades tutelares del panteón asturiano.

En este artículo, y a partir de conocidos trabajos de síntesis ${ }^{4}$, nos proponemos indagar en el jovellanismo «cultural», es decir, en las representaciones literarias, plásticas, filosóficas o políticas de Jovellanos codificadas «desde fuera» de la economía. Todas ellas, indudablemente, unidas por compartir la matriz que aporta la historicidad de cualquier construcción cultural. Usando categorías filosóficas de G. Bueno ${ }^{5}$, diremos que nos interesan las versiones «mundanas» del jovellanismo, por contraposición a las «académicas» ${ }^{6}$-bien sean estas literarias, políticas, económicas...-. La efervescencia de este jovellanismo «mundano» se ha visto favorecido por dos hechos.

En primer lugar, por el carácter enciclopédico e interdisciplinar de la obra de Jovellanos -más de 600 textos en prosa, dos millares de cartas, poesías...-, elaborada en una época en que las ciencias aún construían sus fronteras y definían sus métodos y objetivos. Es decir, propias de un tiempo en que a diferencia de

\footnotetext{
${ }^{2}$ Nos referimos a la elaborada por Moratinos Otero y Cueto Fernández (1998), continuada y ampliada desde el año citado en el Boletín jovellanista y en los Cuadernos de Investigación, ambas editadas por la Fundación Foro Jovellanos (Gijón). Con el fin de no sobrecargar de citas este artículo, las referencias a la bibliografía histórica jovellanista que se formulen sin citar a pie de página, remiten a estas fuentes, todas disponibles en red.

${ }^{3}$ Cfr. Poncela (2010).

${ }^{4}$ Caso González (1978), Sánchez Corredera (2004), De Lorenzo (2011ª), Fernández Sarasola (2011), y Llombart (2012), entre otros.

${ }^{5}$ Bueno (1970), pp. 243-322.

${ }^{6}$ Estas últimas, -que integrarían el jovellanismo «científico»-, puede decirse que, en relación a Asturias, son las que se inician a finales del siglo XIX, con los trabajos de J. Somoza y que se "institucionalizan" desde 1984 con la preparación por J. M. Caso del proyecto de Obras completas de Jovellanos, aún en curso. Todo ello, claro está, sin ignorar las innumerables investigaciones llevadas a cabo fuera de la región.
} 
los actuales -en que «se sabe más y más de menos y menos cosas» (Vargas Llosa)-, abundaban los «especialistas en la totalidad». Hecho que, de algún modo, se ratificaba en el epitafio redactado por Quintana y Gallego en 1842 para la lápida que custodiará los restos del gijonés: «magistrado, ministro, padre de la patria, literato, orador, poeta, jurisconsulto, filósofo, economista...». $\mathrm{Y}$, en segundo lugar, por las propias circunstancias biográficas de Jovellanos: un «personaje-época» en el sentido de vivir en un tiempo convulso de guerra y de transición política, de polarización social e ideológica que exigió de sus protagonistas la toma de partido. Además de sujeto y espectador activo de aquel entorno histórico, Jovino sufrirá sus embates directos -destierro, persecución inquisitorial, cárcel, ofrecimientos de José I, efímero paso por el ministerio, ruina patrimonial, ocaso del Real Instituto..... Al referir en primera persona diarios, correspondencia- la huella en su ánimo de aquellos acontecimientos, dejará materia más que suficiente para futuros exégetas e intérpretes. Para estos últimos, más que el Informe de ley agraria o la Memoria en defensa de la Junta Central, importaban los argumentos biográficos sobre los que construir un Jovellanos «clásico» a la medida de su horizonte espiritual o ideológico.

\section{DE LOS ALTARES ILUSTRADOS AL PANTEÓN LIBERAL}

\section{6-1798: de "hereje impío» a «benéfico astro»}

En 1796 el Santo Oficio condenaba el Informe de ley agraria por considerar las ideas en él vertidas como «injuriosas» a la sociedad estamental, «eversivas de la monarquía e inductivas a la anarquía» y tendentes a «despertar ideas de igualdad en la posesión de los bienes». En 1798, con los rescoldos del anatema aún humeantes, los reconocimientos institucionales a su nombramiento para el ministerio propiciarán la construcción de la primera imagen pública de Jovellanos a través de un completo corpus literario e iconográfico ${ }^{7}$.

La Universidad Literaria de Oviedo, el Colegio de San Ildefonso de Alcalá, la Sociedad de Amigos del País de Asturias, la Junta General del Principado y diversos ayuntamientos, concurrirán al evento en públicas manifestaciones, certámenes literarios, bailes, fuegos artificiales, refrescos, ambigús y funciones teatrales. Odas, silvas y epístolas de poetas locales competirán con las salidas de la pluma de Meléndez Valdés, Quintana o Moratín. La retórica neoclásica deifica a Jovellanos: «benéfico astro», «padre de la luz». En una Oración eucarística leída en Tineo, Asturias contraía con Jovellanos -«protector de la agricultura, promotor de la industria, padre de la patria»- la deuda de haber enseñado a «traer de lejanas tierras el pan para sus hijos, y el de cultivar por sí misma los ricos minerales». Al «nuestro numen, corred colonos», de Meléndez

${ }^{7}$ Cfr. De Lorenzo Álvarez (2011 b), pp. 723-739; Fernández Cabezón (2011), pp. 667-682; Calvo Maturana (2011), pp. 651-665. 
Valdés, se sumará la alegría de Quintana al celebrar «aquel momento en que a las manos del saber se entregan las riendas del poder» ${ }^{8}$.

El «monumento literario» se completará con el iconográfico plasmado en lienzos, arquitecturas efímeras y decorados teatrales cargados de alusiones clásicas. En Oviedo, en 1798, diseñado por Juan de Villanueva, se erigía el primer monumento arquitectónico a Jovellanos, utilizado en 1801 como excusa aparente para su deportación a Mallorca ${ }^{9}$.

\section{Desde 1812: «benemérito de la patria», pero con matices}

Los conflictos con la Francia revolucionaria (1793) y con la napoleónica (1808), remodelan los conceptos de patria y nación, a la vez que crean en las filas liberales la urgencia de construir una historia propia a partir de una relectura diferencial del pasado ${ }^{10}$. En esa línea, el 24 de enero de 1812, dos meses después de su fallecimiento, las Cortes de Cádiz, a propuesta de Toreno, refrendaban el decreto que convertía a Jovellanos en «benemérito de la patria» por razón de su contribución a las luces, su persecución por el despotismo y su «adhesión a la causa nacional». Aquel mismo año, Isidoro de Antillón publicaba la primera biografía del ilustrado con la que se iniciaba la «apropiación» del asturiano por la causa gaditana: «un nombre precioso que añadir al martirologio de la causa liberal» ${ }^{11}$. También en 1812 verían la luz las memorias de González Posada ${ }^{12}$ y, en 1814, la biografía de Ceán Bermúdez.

Pese a las recomendaciones de aquel decreto respecto al Informe de ley agraria -citado en la comisión de agricultura en múltiples ocasiones como fuente de autoridad-, las urgencias del momento harán que las Cortes prioricen los aspectos políticos de Jovellanos en detrimento de sus contribuciones económicas. Y así, desde las filas del liberalismo francófilo no tardarán en surgir las críticas al modelo de constitucionalismo histórico -la «constitución antigua»sostenido por el gijonés. Antillón explicaba que, en su defensa del orden estamental y del bicameralismo, Jovellanos «obraba por reglas de prudencia» en unas circunstancias que lo mantenían «más circunspecto y embarazado de lo que sus mismos principios le hubieran permitido». Desde el Semanario Patriótico se hablará de un «espíritu debilitado por la edad» ${ }^{13}$.

\footnotetext{
${ }^{8}$ Cfr. Derozier (1969), p. 203.

${ }^{9}$ Cfr. González Santos (2011), pp. 3-12.

${ }^{10}$ Cfr. García Cárcel (2004), pp. 3-43.

${ }^{11}$ Cfr. Álvarez Barrientos (2011), pp. 631-649.

${ }^{12}$ Cfr. Caso González (1988), pp. 163-203.

${ }^{13}$ Cfr. Antillón (1812), p. 120 ; Semanario Patriótico, 91 (2 de enero de 1812): cit. en Fernández Sarasola (2011), p. 130.
} 
Más matices. Para Toreno, la integridad moral y el patriotismo de Jovellanos no excluían su anclaje social en un mundo que periclitaba. Para Argüelles, el bicameralismo aludido, resultaba moderado, sin duda porque el gijonés carecía «del arrojo conveniente a una revolución» ${ }^{14}$. En ambos casos, señala Fernández Sarasola, esta corriente liberal, además de ignorar los vínculos establecidos por Jovellanos entre moral y política, postergará su ideario político para dejar reducida la imagen del ilustrado a la del patriota víctima del despotismo. Por su parte, Gil Novales, frente lo que se acaba de exponer, subrayará la paradoja de que ya en 1809 sean los propios invasores los que se refieran a las «ideas liberales» del asturiano, o al hecho de que el Diario Mercantil de Cádiz enfatizase su contribución a la «historia política de nuestra revolución» y a hacer «más amable a los españoles el imperio de la constitución política y más aborrecible la tiranía»: en definitiva, un Jovellanos doceañista ${ }^{15}$.

El liberalismo anglófilo de Blanco White aplaudirá desde las páginas de $E l$ Español (1814) la apuesta bicameral y por el sistema de equilibrio de poderes sostenida por Jovellanos. Pero tampoco en este caso faltarán las precisiones. En Letters from Spain (1822) y en su Autobiografía (1845), Blanco destacará tanto los prejuicios nobiliarios del asturiano como el haber defraudado las expectativas depositadas en su ministerio ${ }^{16}$. Por último, desde El Censor General (1812), o desde la Apología del altar y del trono (1818), de Rafael Vélez, los diputados realistas pondrán en valor justamente aquellas tesis jovellanistas menos queridas por el liberalismo, especialmente las referidas a sus críticas a la soberanía nacional.

\section{USOS Y ABUSOS DE JOVELLANOS: DEL MODERANTISMO AL NEOCATOLICISMO (1820-1868)}

Durante el Trienio, en los diarios de sesiones de las Cortes vuelven a reiterarse las citas del Informe con ocasión de los debates sobre desamortización. No faltan los usos políticos de Jovellanos a partir de su Memoria en defensa de la Junta Central. Si en 1820, en El Censor, volvía a discutirse sobre «supremacía» y «soberanía», al año siguiente, Ramón de Salas, en sus Lecciones de Derecho Constitucional para las escuelas de España (1821), convertía a Jovellanos en precursor del pensamiento político conservador.

\footnotetext{
${ }^{14}$ Las referencias en Toreno -Historia del levantamiento, guerra y revolución de Asturias (1837)y A. Argüelles -Examen histórico de la reforma constitucional...(Londres, 1835)-: cit. en Fernández Sarasola, p. 217.

${ }^{15}$ Gil Novales (1995).

${ }^{16}$ Cfr. Fernández Sarasola (2011), p. 220.En términos más duros, J. García de León y Pizarro escribirá en sus Memorias: «Tan cierto es que este literato distinguido, este sabio legislador, era más a propósito para formar veinte repúblicas de Platón que para gobernar un pueblo de cien vecinos»: cit. en Calvo Maturana (2011), p. 661.
} 
Apenas agotada la década ominosa, comienzan a publicarse, -parcialmente, sin estudios previos ni criterios analíticos- recopilaciones de las principales obras del gijonés: son las ediciones de Carreño (1830-1832), Linares (18391840) y Mellado (1845-1846), entre otras. Para estas fechas, y en la misma medida en que se consolida el nuevo marco institucional, el ideario liberal dejaba de construirse por oposición al absolutista. La aparición de una oferta política más plural, va dejando atrás los anclajes doceañistas. Del mismo modo, y en consonancia con el ambiente europeo -los años del Syllabus, de la «primavera de los pueblos», y de los primeros pasos del socialismo y de las corrientes laicistas-, la idea de nación irá perdiendo su asociación con las categorías de progreso/libertad/constitución, para dotarse de nuevos contenidos, como monarquía, orden, catolicismo ${ }^{17}$.

El cambio de contorno histórico -Estatuto Real, liberalismo doctrinario-, se hará notar en la relectura del legado jovellanista. Toreno y A. Alcalá Galiano, en otro momento encarnación de ala radical del liberalismo, protagonizan en su tránsito al moderantismo una revisión marcada por el énfasis en las tesis relativas a la constitución histórica y la soberanía compartida. Ambos se esforzarán por presentar a un Jovellanos alejado de extremismos, militante del «partido de la sensatez» e integrado en las filas de la «filosofía del sentido común» (Donoso Cortés, Balmes), filosofía que apuntalaba una cosmovisión conservadora del orden social y político ${ }^{18}$. La Sociedad Española de Jovellanos, ligada a Narváez, es otro ejemplo de la revisión a que se hace referencia. Alcalá Galiano explicaba la elección del patronazgo jovellanista por la sociedad citada, por el hecho de que la obra del gijonés expresaba fielmente el ideal ecléctico que la presidía $^{19}$.

Una vuelta de tuerca más en esa apropiación conservadora será la representada por la corriente tradicionalista y neocatólica -Nocedal, Laverde Ruiz, y Menéndez y Pelayo, entre otros-. Paradójicamente, el mismo ideario que lo había convertido en «hereje» lo elevaba ahora a las cumbres de la ortodoxia ${ }^{20}$. En 1858, Nocedal corría con la sexta edición de las obras de Jovellanos. En el estudio preliminar, además de denunciar la apropiación liberal del gijonés «intentan llevárselo a sus filas» a partir de «algún desliz o equivocación de juventud»-, añadía nuevos perfiles doctrinales: elogiaba las «escuelas patrióticas» por él promovidas frente a «las extrañas teorías del derecho al trabajo», o exaltaba su castidad, «prueba de que no llegó a inficionarse con los aires volte-

\footnotetext{
${ }^{17}$ Véase Álvarez Junco (2001).

${ }^{18}$ Sobre esta cuestión, vid. J. Herrero (1973) y Dérozier (1987).

${ }^{19}$ Cfr. Fernández Sarasola (2011), pp. 234.

${ }^{20}$ Vid. Llombart (2102), pp. 211-215.
} 
rianos ${ }^{21}$. Su Vida de Jovellanos (1865), iba acompañada de unos «Juicios críticos» formulados por tres académicos. Para el primero, Fernández Guerra, Jovellanos era el «padre y verdadero fundador del partido conservador o moderado»; para M. Cañete, el asturiano venía a probar que «para amar al pueblo no hace falta la democracia, basta el cristianismo»; por último, para S. Catalina, el ilustrado «no podrá ser incluido sin error en el número de aquellos partidarios del progreso» ${ }^{22}$.

Hubo, desde las filas del integrismo católico, decididos antijovellanistas que repudiaron las tesis nocedalianas. Para Menéndez de Luarca, Jovellanos no podría ser «apóstol de una idea» por cuanto no había hecho otras cosa que «reflejar todos los sistemas sin poner nada nuevo en ellos ${ }^{23}$. La respuesta de Laverde Ruiz restituía a Jovellanos a las filas del tradicionalismo: «liberal pero a la inglesa, innovador pero respetuoso de las tradiciones y dogmas de la Iglesia» ${ }^{24}$. Pero será Menéndez y Pelayo quien desarrolle «uno de los análisis más sagaces y hoy más influyentes» dentro de los actuales defensores del conservadurismo del asturiano ${ }^{25}$. Fuera del «error grave» del Informe en lo que tenía de crítica a la amortización eclesiástica, y del propio hecho de ser economista -«que no es leve pecado»-, la ortodoxia de Jovellanos «resulta acendrada y sin mácula», especialmente la contenida en sus textos sobre educación, «monumento insigne de pedagogía cristiana». Don Marcelino dejará para la posteridad este encendido y sentido juicio: «Varón justo e integérrimo, estadista todo grandeza y desinterés, mártir de la justicia y de la patria, alma heroica y hermosísima» ${ }^{26}$.

\section{DEL SEXENIO A LA RESTAURACIÓN: JOVELLANOS DEMÓCRATA, REPUBLICANO Y REGENERACIONISTA}

Los vínculos entre republicanismo e ilustración cuentan con una historiografía propia que los documenta ${ }^{27}$. Señalaba Polt que la correspondencia entre Jovellanos y Cabarrús en 1808 -«España no lidia por los Borbones (...), lidia por sus propios derechos, superiores e independientes de toda familia o dinastía»-, había dado pie a que se considerase aquella como una eventual declaración de republicanismo, tesis mantenida en su tiempo por G. de Azcarate. Por su

\footnotetext{
${ }^{21}$ Nocedal [1858-9] (1952 y 1963), I, pp. vi y liv. El primer tomo, precedido de un «Discurso preliminar» (1858), y el segundo de un «Prólogo» (1859), ambos editados en obra exenta en 1865 como Vida de Jovellanos, Rivadeneyra, Madrid.

${ }^{22}$ Cfr. Nocedal (1865), pp. 217, 235 y 257.

${ }^{23}$ Cit. en Sánchez Corredera (2004), p. 317.

${ }^{24}$ Cfr. Laverde Ruiz (1868), pp. 394-406.

${ }^{25}$ Cfr. Llombart (2012), p.212.

${ }^{26}$ Cfr. Menéndez y Pelayo [1882] (1947), vol. V, lib. VI, cap. III, pp. 293-409.

${ }^{27}$ Vid., entre otros, Álvarez Junco (1994), Ruiz Manjón (2002), y Sánchez Collantes (2012).
} 
parte, Sánchez Collantes ha encontrado en la prensa demócrata y republicana pionera -La Discusión (1858), La Joven Asturias (1865)- numerosas evocaciones jovellanistas. En 1873, apenas proclamada la República, nueve concejales gijoneses proponían erigir por suscripción popular un monumento a Jovellanos en memoria del nuevo régimen. Ya en las sesiones parlamentarias de 1869, el ilustrado asturiano será invocado reiteradamente por sus valores ciudadanos y como «héroe civil». Otro tanto cabe decir de la prensa -El Motín, El Nuevo Régimen, La República ...- y de la publicística republicana de aquellas décadas -M. Pedregal, Vera González, Pi y Margall...-, desde la que se recupera su reformismo agrario, su programa educativo o su sensibilidad social hacia el pueblo trabajador.

Del mismo modo, la actualidad del debate agrario durante la segunda mitad del siglo, prolongará el legado del Informe, y ello a pesar de que la progresiva institucionalización académica de los estudios económicos alejaba a estos de las referencias doctrinales ilustradas ${ }^{28}$. Las tesis de Jovellanos servirán tanto para su discusión desde la economía -de Flórez Estrada a Madoz y J. Costa, pasando por Canga Argüelles, Garrido o Jaumeandreu-, como desde la agronomía González Alonso, Álvarez Guerra, Fermín Caballero-. Llombart ha subrayado tanto los usos críticos del Informe -Colmeiro para poner en cuestión la coherencia doctrinal del mismo; Costa para destacar la ruptura entre el «individualismo radical» de Jovellanos, extraño a la tradición colectivista agraria-, como la distorsión derivada de «introducir a su autor en la arena política decimonónica y, naturalmente, en las luchas ideológicas de una época que ya no era la suya» ${ }^{29}$.

En la arena política, se habían iniciado las críticas a la versión neocatólica, aún activa, del ilustrado. El hispanista Baumgarten lo hacía en 1877, y G. de Azcárate en 1881. Sus opiniones fueron contestadas con displicencia por Menéndez y Pelayo: «el krausista Azcárate y sus cofrades de la Institución Libre, viven olvidados de las cosas de su patria» ${ }^{30}$. En 1880, desde La Ilustración Gallega y Asturiana y desde la Revista de Asturias -entre sus colaboradores figuraban Palacio Valdés, Leopoldo Alas y Adolfo Posada-, se insistirá en conectar a Jovellanos con la tradición ilustrada y liberal. Los mismo ocurrirá en una edición de obras escogidas de Jovellanos realizada en 1887 por F. Soldevilla, y en cuyo prólogo arremetía contra las tesis «insidiosas» y faltas de fundamento de Nocedal $^{31}$.

${ }^{28}$ Almenar Palau (2002), pp. 81-204; Robledo Hernández (1993), pp. 48-80.

${ }^{29}$ Cfr. Llombart (2012), pp. 214-215.

${ }^{30}$ Cfr. Álvarez-Valdés (2012), pp. 791-792; Azcárate (1880), p. 442, y Menéndez y Pelayo (1882) (1947), lib. VI, cap. III, p. 339.

${ }^{31}$ Cfr. Soldevilla (1887), pp. xx-xxi. Era la cuarta de las ediciones de obras escogidas realizada en los años ochenta, junto a las de J. Alonso del Real (1884), Biblioteca Clásica Española (1884), y Biblioteca Clásicos españoles (1886) 
Tampoco Jovellanos iba a pasar desapercibido para el krausismo español. Frente al optimismo de Bastiat y el de la «escuela economista», esta corriente Giner de los Ríos, Azcárate, Piernas Hurtado, Álvarez Buylla...- reivindicará tanto la necesidad equilibradora del Estado frente al mercado, como los puentes entre orden natural y moral ${ }^{32}$. Igualmente, se ha puesto de relieve cómo en los autores regeneracionistas -Picavea, Costa, Mallada, Ganivet- y en los de la generación del 98, latía una compartida reacción reformista y social frente a la «cuestión social» y a la crisis de los valores que impregnaba todo el sistema político de la Restauración ${ }^{33}$. Por lo mismo, nada tiene de extraño que Giner, Costa o Altamira, como Azorín o Baroja, se considerasen «hijos espirituales» de Jovellanos y reivindicasen su proyecto educativo ${ }^{34}$. Estrechando más el análisis, Lissorgues ha puesto en relación el reformismo agrario de Jovellanos con los artículos de Leopoldo Alas (Clarín) aparecidos en El Día (1883), o con la Memoria acerca de la información agraria en ambas Castillas (1904), de A. Buy$11 a^{35}$.

Con deudas hacia el regeneracionismo, en 1887 se constituía en Asturias la sociedad La Quintana con vistas a la recuperación de la cultura regional. Entre sus filas militaría Julio Somoza, con quien se iniciará el primer programa sistemático de catalogación, recuperación y edición crítica de la obra de Jovellanos, dejando atrás los afanes de las «sectas políticas»-incluida la tradicionalista- por convertirlo en bandera de sus intereses. En 1901, en uno de sus trabajos más significativos, escribía estas sensatas reflexiones:

«De tanto copiar y manosear la biografia de Ceán, se han dejado en el olvido los escritos y trabajos alli recogidos. Afirmamos que como economista, se ha dicho poco de él. No ha llegado hasta nosotros noticia alguna de libro en que se examinen sus escritos sobre el fomento de la riqueza nacional. Claro que todo este trabajo pide estudio reconcentrado y largo examen y dotes no vulgares de exposición y análisis. Se precisa hacer en loor suyo algo más permanente y eficaz que estatuas, monumentos [...]. Pueden estos signos externos probar la gratitud o admiración, pero hay en su exterioridad algo que responde más bien al orgullo que no a la representación pura. Esta simbolización aparece mejor en el libro, confidente mudo y expresivo del corazón humano, representación más pura y modesta que los fríos monumentos de bronce y granito» ${ }^{36}$.

\footnotetext{
${ }^{32}$ Menéndez Ureña (2001); Malo de Guillén (2001); Serrano Sanz (1997).

${ }^{33}$ Fernández Clemente (2001), pp. 557-580.

${ }^{34}$ E. Díaz (2002); D. T. Gess (1999); Ruiz Berrio (1993).

${ }^{35}$ Cfr. Lissorgues (2011), pp. 703-723. En 1945, Barcia Trelles confesaba que se había acercado a Jovellanos a raíz de escuchar a Clarín en una conferencia, "El materialismo económico", pronunciada el 22 de enero de 1900 en un curso de Extensión Universitaria celebrado en Gijón.

${ }^{36}$ Cfr. Somoza (1901), pp. 16 y 28.
} 


\section{JOVELLANOS EN LA "REPÚBLICA DE LAS LETRAS"}

En 1873, en La corte de Carlos IV, Galdos homenajeaba indirectamente a Jovellanos al contraponer su honestidad a la corrupción de «figurones» como Godoy o Caballero: «su poderío esta cosido por hebras de seda que las tijeras de una mujer pueden cortar $\rangle^{37}$. Dos años después, en 1875, con 23 años, un romántico y rebelde Clarín componía su «Oda a Jovellanos»: en una «España tumba de antiguas libertades», lo presentaba como adalid del liberalismo ${ }^{38}$. Años después, en 1892, ya desde la militancia regeneracionista, dedicaba en el Madrid Cómico un «palique» a la inauguración en Gijón de la estatua a Jovellanos ${ }^{39}$, a la que consideraba expresión del «mal gusto reinante y de la decadencia de los valores auténticos». Lamentaba, además, que tras ochenta años de olvido, el acto no hubiera revestido carácter nacional y que careciese de representantes de la Corona o del gobierno. Fustigaba la elección por Pidal del conde de Revillagigedo -«incapaz de pronunciar una erre doble»- como representante de la reina. En fin, el acto fue «la cosa más cursi posible», con juegos florales, «con señoritas reinas temporeras del cotarro», y con un himno en loor de Jovino encargado «a uno de los vertebrados menos líricos del reino: Pobre Jovellanos, siempre perseguido por la reacción!».

En 1894, esta vez con ocasión del centenario de Instituto Asturiano, desde la misma publicación escribiría: «Le tengo un cariño casi instintivo, apenas razonado, que es una especie de culto». También se pronunciaba respecto al Informe de ley agraria, un «monumento de economía aplicada, según entonces esta ciencia podía entenderse ${ }^{40}$. En 1898 , ensayaba una versión social y política novedosa:

"Al cruzar las anchuras de Castilla, no pensaba Jovellanos ni siquiera en el Cid, y mucho menos en las hazañas de los tercios en Flandes [...], pensaba en futuros días de trabajo honrado, asiduo y eficaz que pudiesen traer consigo la riqueza [...]. De entonces acá, Castilla y lo demás de España que se le parece, poco ha cambiado. Hemos seguido perdiendo riquezas advenedizas, el botin, que nos tenía orgullosos y daban pretexto a la holganza. Hemos perdido más y hemos hecho muy poco por reemplazarlo con lo que Jovellanos tenía por conquistas reales del porvenir» ${ }^{41}$.

En 1893, Rodríguez Carracido, primer catedrático de bioquímica de España

${ }^{37}$ Pérez Galdós [1873] (1929): cap. XVII, p. 184.

${ }^{38}$ Cfr. Alas (2006), tomo XI, pp. 1182-1187.

${ }^{39}$ Alas [1892]: "Preparativos del centenario" -en Madrid Cómico, 478-, Obras completas, 2006, VII, pp. 188-191; Lissorgues (2010), pp. 141-152.

${ }^{40}$ Alas, Clarín [1894]: "Epifanía" -en Madrid Cómico, 570-, Obras completas, 2006, VIII, pp. 643-647.

41 "Revista mínima" en La Publicidad, 20 de junio de 1898: cit. y reproducido en De Lorenzo (2011), p. 329. 
y distinguido ateneísta, convertía al gijonés en protagonista literario de su Jovellanos. Ensayo dramático-histórico, una obra ambientada entre 1791 y 1811. En el prólogo, elogiaba al ilustrado presentándolo como un estadista inmune al contagio de «la ponzoñosa atmósfera de su tiempo», intransigente a la máxima tan presente en la España finisecular- de que el fin justifica los medios. Por todo ello, recriminaba a quienes, como Silvela, hacía suyas las críticas de Godoy a la «filosofía estrecha y severa» de Jovino ${ }^{42}$.

La aproximación azoriniana a Jovellanos, fue, como advierte Elena de Lorenzo, puramente evocativa: «busca en la Ilustración lo que quiere encontrar», busca en Meléndez, Cadalso y Jovellanos las raíces de un prerromanticismo que la historiografía literaria acabará por consagrar ${ }^{43}$. Por otro lado, compartirá con Juan Valera su deslumbramiento por la prosa del gijonés, que lo convertían en la «más alta autoridad literaria de España». Más allá del estilo, Azorín -al igual que el Unamuno de En torno al casticismo (1902)-, encuentra en el Informe una de las piezas más altas de la literatura sobre «los males de España», en línea con la obra de Ganivet y de otros autores del regeneracionismo ${ }^{44}$.

\section{JOVELLANOS ENTRE DOS CENTENARIOS (1911-2011)}

El primer centenario de la muerte de Jovellanos va a dar ocasión a una notable efervescencia de publicaciones institucionales. Aún cuando la mayor estabilidad política había propiciado una historiografía más positivista y profesionalizada, menos romántica y providencialista, seguirán manteniéndose arraigadas las dos corrientes o modelos interpretativos ya vislumbrados en el pasado, el liberal/krausista (Altamira) y el conservador (Ballesteros). La Real Academia de la Historia dedica un boletín monográfico al gijonés -Jovellanos en la Real Academia de la Historia- recogiendo su intensa labor como censor. La Academia de Ciencias Morales y Políticas editará los ensayos premiados en una convocatoria sobre las doctrinas morales y políticas del gijonés. En algunos de ellos se insistía en la vertiente religiosa (García Rendueles) o neocatólica (H. Yabén, García de Artiñano); en otros se trataban de ofrecer síntesis integradoras (J. Juderías) o se le presentaba como un radical y progresista que no había llegado «ni a ser filósofo ni a fundar escuela» (Camacho y Perea). Para el profesor Caso, del medio centenar largo de publicaciones gestadas en torno al centenario -que apenas pasaban del vano intento «de salvar a Jovellanos para una actitud política o religiosa de derechas»-, únicamente se salvaba la publicación por

\footnotetext{
${ }^{42}$ Sobre Rodríguez Carracido: A. Moreno Sánchez (2003).

${ }^{43}$ Cfr. De Lorenzo (1999); Rubio Cremades (1993).

${ }^{44}$ Azorín [1913] (1959).
} 
Somoza de la correspondencia entre el gijonés y lord Holland ${ }^{45}$.

En Gijón, además de ciclos de conferencias en el Ateneo y de un número monográfico de El Comercio -con artículos escasamente novedosos de Azcárate, Unamuno, Maura, González Besada, Pidal y Mon...-, se editó un álbum ilustrado -Centenario de Jovellanos- donde no dejan de reiterarse lugares comunes: Unamuno elogiaba «el buen sentido práctico» del ilustrado; Azorín, su «prosa limpia y clara»; Palacio Valdés, su rectitud moral; Rafael María de Labra la importancia de las Sociedades Económicas como iniciadoras de la «revolución contemporánea española», y J. M. Pedregal el programa económico jovellanista para Asturias. Todo ello rematado por un poema del agustino Jesús Delgado en el que se canta al «gran Jovino, atlante de la patria, del trono y del altar». En fin, Caso tenía razón.

Además de la referida publicación de Somoza, son dignas de recordar las conferencias de Azcárate y de E. González Blanco en el Ateneo. El primero, en Jovellanos y su tiempo, revisaba la figura de Jovellanos «como cooperador de la obra realizada por la revolución en su primera etapa». González Blanco -El patriotismo de Jovellanos-, además de restablecer las continuidades entre el ilustrado y Costa, ofrecía una visión del mismo más republicana, laica, antiescolástica y social ${ }^{46}$. El centenario, como final no esperado, contará con la fundación en Gijón, en 1912, de la Logia Jovellanos, presentada en sociedad en 1915 como una agrupación defensora de una moral laica y cosmopolita. Se venía a sumar a la constituida en Luarca con igual nombre en 1891, y ambas integradas por profesionales liberales y comerciantes de ascendencia republicana y melquiadista ${ }^{47}$.

Durante el primer tercio del siglo, la labor editora no se detuvo. Salvo extorsiones puntuales -como en los casos de Martínez Noval o de Vázquez de Me$11 a^{48}$-, el jovellanismo se remansa y el ilustrado será paulatinamente «trasladado

${ }^{45}$ Se refería a Documentos para escribir la biografía de Jovellanos (1991), 2 vols. Cfr. Caso González (1978). Para una perspectiva más amplia de las publicaciones suscitadas por el centenario -entre las que se incluye la primera tesis doctoral sobre las ideas pedagógicas de Jovellanos-, véase Sánchez Corredera (2004), pp. 359-407.

${ }^{46}$ Las dos publicaciones a que se hace referencia: Centenario de Jovellanos (Imp J. Blass y Ca, Gijón, 1911), y El Ateneo de Gijón en el centenario de Jovellanos. Conferencias y lecturas (Tip. La Industria, Gijón, 1911).

${ }^{47}$ Pozuelo Andrés (2012), pp. 25-34.

${ }^{48}$ El primero señalaba que la muerte de Jovellanos en 1811, «bajaba al sepulcro el hombre que había representado las últimas energía de un pueblo varonil»-Jovellanos (1911), reeditado en 2006 por la Fundación Foro Jovellanos-. Vázquez de Mella, en conferencia pronunciada en Oviedo en 1916, asimilaba a Jovellanos al ideario de Capmany e Inguanzo pese a que «sufría flaquezas y desvaríos en lo que se refiere a la parte económica» por la perniciosa influencia sobre él ejercida por Campomanes y Adam Smith -Obras completas, II, p. 225 (Barcelona, 1933). 
de los altares civiles al relativismo de los hechos históricos» ${ }^{49}$. En 1911, E. Gonzaléz Blanco daba a la imprenta una nueva biografía -Jovellanos, su vida y su obra-, y en 1915, M. de Adellac editaba los diarios. En 1917, quien sería alma de la Revista de Occidente y miembro de la generación del 27, Fernando Vela, convertía al gijonés en adalid de la lucha por una educación moderna ${ }^{50}$, contrariando así las tesis de Ortega referidas a la ausencia en España del «siglo educador».

Al margen de reediciones de obras selectas y escogidas, o de obras sueltas El delincuente honrado (1927), Memoria en defensa de la Junta Central (1928)-, los principales avances en el estudio de la obra de Jovellanos, correrán a cargo de Somoza, Ángel del Rio y Huici Miranda. Este último, editaba en 1931 una colección de textos inéditos del asturianos -las cartas a Godoy, entre ellos-, precedida de un elocuente prólogo de Somoza - «Jovellanos no es, ni puede ser nunca, en el sentido vulgar, un hombre "popular")», en el que volvía a lamentar los manuscritos perdidos o fuera de localización «por el necio afán de posesión absoluta» que los hurta a la investigación ${ }^{51}$. Ángel del Río, en la introducción a su edición de obras escogidas de Jovellanos, reclamaba un análisis histórico del ilustrado que lo alejase de encasillamientos, a la vez que se detenía en su fuentes doctrinales y explicaba el «saludable» eclecticismo de su obra, poniéndola en relación con la etapa de transición que le había tocado vi$\mathrm{vir}^{52}$.

Los años de la República instrumentalizarán los perfiles más reformistas de la obra de Jovellanos: Morán Bayo, desde la perspectiva agraria, Álvarez Santullano desde la pedagógica, y Emilio Robles, desde la social ${ }^{53}$. Cuando ya la guerra se había instalado en Gijón, Luis Piñer, evocaba a Jovellanos en aquella «hora terrible, de lodo, de muerte, de regresión» como estímulo urgente a la lucha por la libertad» ${ }^{54}$. Luego, tras la guerra civil, vendrá el silencio. La ley de 20 de septiembre de 1938 no ofrecía dudas al recomendar en los manuales de historia la «revalorización de lo español» y la «extirpación del pesimismo antihispánico y extranjerizante». Las visiones esencialistas de lo hispano -con deudas hacia la Defensa de la hispanidad (1934) de Maeztu-, no se harán esperar ni en los ensayos -Historia de España contada con sencillez (Peman, 1938), Genio de España (Jiménez Caballero, 1938), El imperio de España (A. Tovar, 1941), Idea de hispanidad (García Morente, 1943)...-, ni en manuales de la época. Un

\footnotetext{
${ }^{49}$ Sánchez Corredera (2004), p. 405.

${ }^{50}$ Cfr. Vela [1915] (1950), pp. 28-30.

${ }^{51}$ Cfr. Somoza (1931), p. 11.

${ }^{52}$ A. del Río (1935).

${ }^{53}$ Moran Bayo (1931), Álvarez Santullano (1936), Robles Muñiz (1932), pp. 70-94.

${ }^{54}$ Piñer [1936] (2010), p. 44.
} 
tratado representativo de lo que habría de ser una «educación patriótica», el de Floriano Cumbreño, sentenciaba que:

«El siglo XVIII fue para nosotros de evidente decadencia y, a falta de otra cosa, esgrimimos los nombre de Feijoo, Jovellanos..., quienes, con más buena voluntad que acierto, condensaron toda la ciencia de nuestro neoclasicismo. Sufría España las consecuencias de su excesivo enamoramiento de las cosas francesas, y eso ha sido siempre la señal más evidente de aquella decadencia» ${ }^{55}$.

El segundo centenario del nacimiento de Jovellanos escenificará la brecha cultural entre las dos Españas. Desde Gijón, una comisión creada en 1943, proponía, sin éxito, la adquisición de la casa natal del ilustrado para convertirla en Museo, además de elevar al Vaticano una petición formal para que el Informe saliese del index. Otros proyectos -editar los diarios, restablecer la escuela de náutica, traslado de cenizas...-, hubieron de esperar por falta de fondos y de acuerdo. Bonet publicaba en 1944 unas grandezas y desventuras de Jovellanos, herederas de la interpretación nocedaliana, y a la que seguirá, en 1952, un poema dramático, en línea con el teatro histórico de Peman y en el que se ponía en boca de ilustrado esta lindeza: «ni propiedad colectiva ni democracia» ${ }^{56}$.

Desde Madrid, Casariego -y en menor medida la Matritense- se erigirá desde la dirección del El Alcazar en el gran animador de la efeméride. En 1943, hacia preceder su Jovellanos de ésta emotiva «ofrenda»:

«A la memoria insigne y nunca bastante exaltada de Jovellanos, de Inguanzo, de Cañedo, que supieron mantener los grandes ideales de la raza frente a la miopia de los conservadores y a traición estéril del liberalismo afrancesado e impio en los años angustiosos en que se hundía el mundo antiguo para dar paso a la etapa burguesa y liberal que ahora periclita»

Tras vincularlo «de modo indudable a la posición tradicionalista y antiliberal», negaba su adscripción doctrinal al liberalismo económico: «se daba cuenta de que una nación atrasada y apática necesita eso que llamamos autarquía ${ }^{57}$. El mismo Casariego sería el autor del guión de un documental conmemorativo de Justo de la Cueva. En el expediente de censura se lee el objetivo del mismo: «exaltar tal figura como valor católico y españolísimo y defensor de la unidad y de la tradición» ${ }^{58}$.

La réplica y contrapunto a tanta extorsión, vendrá de la España del exilio, y del homenaje de los Centros Asturianos de Buenos Aires, La Habana y México a través de la obra colectiva, Jovellanos, su vida y su obra, con colaboraciones

\footnotetext{
${ }^{55}$ Cfr. Floriano Cumbreño (1944), p. 95.

${ }^{56}$ Bonet (1944) y (1952).

${ }^{57}$ Casariego (1943), pp. 1, 107 y 125. Sobre el homenaje de la Matritense, vid. la conferencia de M. Barber, su director, en Homenaje a Jovellanos (Gráfica Informaciones, Madrid, 1944).

${ }^{58}$ De Lorenzo (2011), p. 304.
} 
de Barcia Trelles, Ossorio Gallardo, Francisco Ayala, Prados Arrarte y Claudio Sánchez Albornoz, entre otros. Al rigor y novedad de los ensayos -caso de los dedicados al Jovellanos asturianista (Cimorra), al Jovellanos economista ${ }^{59}$ (Prados), o a la influencia americana de Jovellanos-, ha de añadirse lo que el homenaje tenía de reivindicador de los valores democráticos del jovellanismo -tolerancia, ciudadanía- frente a lo que don Claudio Sánchez Albornoz llamaba «los bárbaros odios hispanos» ${ }^{60}$.

\section{Jovellanos «académico» versus Jovellanos «mundano»}

La construcción académica o «científica» de Jovellanos, impulsada desde 1952 por el profesor Caso, cimentada por Artola, al culminar en 1956 la edición de la Biblioteca de Autores Españoles, y fortalecida por el hispanismo -Sarrailh, Herr, Domergue, Deforneaux, Rick, Polt...-, acabará por cristalizar en el proyecto de Obras completas que, iniciado en 1984, asiste hoy a sus últimas etapas. El mejor conocimiento sectorial -escritos jurídicos, económicos, literarios, políticos, artísticos- o microsectorial -aproximaciones a Jovellanos desde las bibliotecas, el deporte, la lengua, la antropología, la gastronomía...-, o las 31 tesis doctorales leídas entre 1931 y 2000, han sido posibles a partir de la puesta al día de una nueva base documental, así como de la mejor contextualización europea y regional de las luces españolas -de la que es buen ejemplo el recién celebrado I Congreso Internacional Jovellanos (1811-2011) ${ }^{61}$. Por fortuna, el mejor conocimiento de la obra de Jovellanos, no ha excluido la tensión científica entre interpretaciones que compiten en fuentes, hipótesis o en metodología por ofrecer visiones más aquilatadas y críticas de las diferentes tesis expuestas en la obra plural de Jovellanos. Por recientes, son bien conocidas las relativas a las interpretaciones del Informe de ley agraria, o las referidas al pensamiento político de Jovellanos ${ }^{62}$.

Ahora bien, la «profesionalización» del jovellanismo no ha impedido que subsistiese aquella línea editorial que al principio de estas páginas se ha calificado de «mundana». Un jovellanismo que, como ocurriera en el pasado, resucita

${ }^{59}$ Como ha señalado Llombart, el estudio de Prados puede considerare como el primer análisis riguroso sobre la ideas económicas de Jovellanos, con el valor añadido de haber suscitado el primer debate académico -protagonizado por J. M. Naharro desde las páginas de Moneda y Crédito (1947)- sobre las corrientes doctrinales de la ilustración económica española. Cfr. Llombart (2012), pp. 216-218.

${ }^{60}$ Este sentido de la obra será reivindicado por Ayala cuando, en 1992, se reedite por separado su colaboración -Jovellanos, sociólogo-. Véase al respecto J. Cela (2003).

${ }^{61}$ Sus actas han sido editadas por Acción Cultural Española y el Instituto Feijoo de Estudios del Siglo XVIII: E. de Lorenzo, I. Fernández Sarasola, J. Ocampo y A. Ruiz de la Peña (eds.) (2011).

${ }^{62}$ Se recogen en Llombart (2012). 
de sus cenizas al calor de las ofertas y demandas de un mercado cultural condicionado por las coyunturas económicas y políticas de cada momento transición política, emergencia del regionalismo...-. Junto a una línea ensayística, filosófica o política, formulada desde criterios académicos y con voluntad de síntesis -Gómez de la Serna, Marañón, López Aranguren, Julián Maria, Laín Entralgo, Lázaro Carreter...-, no han faltado desde este mismo género los «abusos» interpretativos al servicio de causas políticas declaradas.

En 1979, Fraga Iribarne analizaba a Jovellanos «desde la perspectiva de la sociedad española actual». Dos años después, convertía las tesis constitucionales del ilustrado en eslabón doctrinal -con Balmes, Canovas, Maura y Maeztude la tradición conservadora española ${ }^{63}$. Se trata de una línea interpretativa que no ha dejado de reproducirse desde el espacio político -Álvarez Cascos, García de Leaniz- o desde el académico ${ }^{64}$. Tampoco han desaparecido las versiones integristas. Así, para Elizalde, «Jovellanos está donde sus escritos le colocan, que no es otro lugar que el del pensamiento contrarrevolucionario y tradicionalista español» ${ }^{65}$. Con mayor sosiego y objetividad, no faltan las hipótesis que acercan algunos textos de Jovellanos a planteamientos federalistas ${ }^{66}$.

Esa misma dialéctica en torno al ideario jovellanista no ha dejado de reproducirse en la prensa periódica. Entre 1994 y 1997, al calor de diversas conmemoraciones relacionadas con el gijonés -bicentenario del Real Instituto, de su nombramiento para el ministerio-, A. Sastre, J. Tussel, F. Álvarez Cascos, Jiménez Losantos o J. L. Cebrián, entre otros muchos, volvían a replantearse el no por secular menos inútil dilema de un Jovellanos conservador o progresista. El discurso de ingreso de Cebrián como académico de la Historia en 1997, ponía en valor las obras de Jovellanos en relación con la transición política española ${ }^{67}$. En ocasiones, la prensa ha servido también de escenario de divulgación de confrontaciones académicas entre visiones neocatólicas o laicas de la obra del ilustrado ${ }^{68}$.

${ }^{63}$ Fraga Iribarne (1979) y (1981). Una respuesta en C. Seco Serrano (1982).

${ }^{64}$ Álvarez Cascos, F. (1998) y García de Leaniz (2012) entre otros. Gómez Ochoa (1995), califica a Jovellanos como «conservador liberal y reformista». En esa misma línea interpretativa: Álvarez Conde (1977) y Piqueras Arenas (2008). Una visión «conservadora» alternativa en G. Anes (1994).

${ }^{65}$ Elizalde (1995), p. 265.

${ }^{66}$ Lo señalaba P. de Silva (1995) a partir de algunos fragmentos del Informe sobre la financiación de las obras públicas, y suponiendo la lectura por el gijonés de los textos de Hamilton, Maddison y Jay aparecidos en El Federalista (1788, New York).

${ }^{67}$ Sánchez Corredera (2004), pp. 562-563; El País, 19 de mayo de 1997 y 27 de noviembre de 1998; M. Martín Ferrand (2004): "Jovellanos entra en campaña", $A B C, 5$ de marzo de 2004.

${ }^{68}$ La posiciones neocatólicas más recientes las encarnaba el presidente, hasta 2013, de la Fundación Foro Jovellanos, J. Menéndez Peláez: "El humanismo cristiano de Jovellanos", en La 


\section{MÁS ALLÁ DE GOYA: REPRESENTACIONES DE UN CLÁSICO}

\section{Jovellanos novelado y versificado: escasa suerte literaria}

La reconstrucción literaria de Jovino no ha estado a la altura de la consagrada por Goya en sus lienzos. En 1969, Reinaldo Arenas novelando las peripecias del dominico novohispano fray Servando Teresa de Mier (1763-1827), describía el ambiente de corrupción que reinaba en la Corte en los tiempos en que Jovellanos ejercía como ministro de Gracia y Justicia y sufría los maltratos de Godoy ${ }^{69}$. Con más densidad y heterodoxia -y con más oportunismo que talento-, Jovellanos es convertido por Gómez Ojea en protagonista de Pentecostes (1989). Un Jovellanos, el de los diarios, inicialmente «andrógino, fastidioso, célibe quisquilloso, clérigo marica» y capaz «de desgarrarse moralmente hasta el heroísmo pero no de comprometerse», irá ascendiendo en la escala sentimental de la alcohólica protagonista hasta convertirse en compañero de viaje de su desgarrada soledad. La polémica suscitada por la obra, por otro lado esperada, no ha mejorado la calidad del texto.

En 1990, Oscar Muñiz -Bobes o la cólera de Dios- recreaba al caudillo astur José Tomás Bobes, «el león de los llanos», antiguo alumno del Real Instituto Asturiano de Náutica, y que guarda como un tesoro hasta su muerte el «no nos defraudarás» que le dirige Jovellanos a su marcha a ultramar. El recuerdo de su paso por el Instituto sirve para traer a colación las supuestas pláticas de Jovino a los jóvenes alumnos: «nada bueno se puede esperar de los revolucionarios en el Gobierno, y todo de la mejora de las ideas». En busca de Xovellanos (2006), novela de Ismael González Arias ambientada en la guerra contra la Francia invasora, Jovellanos es la disculpa para argumentar la vida aventurera de un joven al que su madre, supuesta amante de Jovino le confiesa: «siempre quise pensar que Jovino fuera tu padre». Y poco más.

Poco que ver tiene el Jovellanos novelado con la altura poética a que lo eleva Luis García Montero en su recreación «El insomnio de Jovellanos» - Habitaciones separadas (1994). Un monólogo que se desenvuelve en el Castillo de Bellver y en el que las convicciones morales de Jovino se yerguen como antídoto a la desesperanza del fracaso del sueño de las luces: «Porque sé que los sueños se corrompen, he dejado los sueños...». En 2011, coincidiendo con el bicentenario, A. Gamoneda compondría el texto de una cantata, Oda a Jovellanos -interpretada por el tenor Joaquín Pixán con música de la Orquesta Sinfónica del Principado- que nutrida de los mismos escenarios del «El insomnio» -el

Nueva España, 6 de enero de 2012. La réplica en A. Ruiz de la Peña Solar: “A vueltas con la fe de Jovellanos", La Nueva España, 22 de diciembre de 2012.

${ }^{69}$ Sobre Reinaldo Arenas y su novela El mundo alucinante (1969), vid. E. San José (2012) 
mar, la soledad, la desafección hacia un tiempo presente escasamente alentador-, servía para reclamar la vuelta de Jovellanos, «clavo de oro en la conciencia lívida de España», «maestro de la sombras, capitán de la luz».

\section{Suerte dispar del Jovellanos monumental}

En 1901, Somoza, en su Inventario, consagraba dos capítulos a las representaciones de Jovellanos. El primero - «Pintura, grabado, escultura»- contiene un inventario pormenorizado de sus retratos, tanto de los realizados por Goya, como de los depositados en instituciones asturianas -ayuntamiento de Gijón, Sociedad Económica, Universidad de Oviedo- y madrileñas -Congreso de los Diputados-, salidos de los talleres de Mariano Sánchez, V. Albiol, Suárez Llanos o Casado del Alisal. A esa relación habría que añadir los creados con posterioridad a la redacción del Inventario -los de Nicanor Piñole, Pelayo Ortega, Javier del Río...-, además de los numerosos grabados y litografías en ellos inspirados -desde Folgueras a Jaime Herrero- y reproducidos en ediciones impresas, medallas conmemorativas, lápidas ${ }^{70} \ldots$

Las representaciones monumentales de Jovino no han gozado de buena sa$\operatorname{lud}^{71}$. Ya se hizo referencia al monumento erigido en Oviedo en 1798 con ocasión de su nombramiento como ministro, y con diseño del arquitecto del Museo del Prado, Juan de Villanueva. Inicialmente adosado a la muralla de Oviedo, orientado al norte, hacia la carretera de Gijón, sufrirá tortuosos traslados -en 1859 es desmontado y adosado al monasterio de San Pelayo, y, en 1938, por indicación de L. Menéndez-Pidal instalado en su ubicación actual-, además de mutilaciones que lo privaron de los múltiples elementos arquitectónicos y decorativos que lo enaltecían. Si en 1801 se iba a usar el monumento como un elemento más de la deportación de Jovellanos como inspirador y redactor del texto de la inscripción, en 1823, con la reacción absolutista, será «salvaje y gratuitamente mutilado» ${ }^{72}$.

Aunque en sentido polémico, el monumento público que Gijón le dedicara en 1891 no correría mejor suerte. Los antecedentes de la idea se remontan a mediados de siglo, cuando la propuesta de Nocedal de levantar una «estatua semicolosal en bronce» es aprobada en 1865 por Narváez. La idea será actualizada en 1873, recién proclamada la República sin que llegase a buen puerto. Retomado el proyecto en 1891, se decide la ubicación del mismo en la plaza de la Puerta de la Villa, rebautizada como Plaza del Seis de Agosto para conmemo-

\footnotetext{
${ }^{70}$ Cfr. Somoza (1901), pp. 203-223; De Lorenzo (2011), pp. 291-359; González Santos (2012), pp. 60-71.

${ }^{71}$ Para un detalle más amplio sobre bustos y representaciones, remitimos al lector al catálogo de la exposición conmemorativa del bicentenario de su muerte: La luz de Jovellanos (2011).

${ }^{72}$ González Santos (2011), pp. 3-12.
} 
rar el día de 1811 en que Jovellanos vuelve a la villa tras su prisión mallorquina. En 1888, Somoza, anticipándose al proyecto, lamentaba la «mezquindad» del premio que convocaba el diseño, así como la «estrechez» de criterios, responsables de la ausencia de escultores españoles de renombre a la convocatoria. A la hora de repartir culpas, Somoza dirige sus críticas a la comisión encargada de la propia convocatoria y a la Academia de San Fernando por no haber estudiado la representación más conveniente a un espacio público. Al final, el escultor Manuel Fuxa- tendría que ceñirse al proyecto canónico que se le encargó: un Jovellanos togado cuyo diseño contó con el asesoramiento de Menéndez y Pelayo. El Jovellanos esculpido nada tenía que ver con el fundador del Real Instituto: «ni estaba calvo, ni grueso, ni usaba semejante ropaje -un traje que nunca usó en su patria, que nada dice a sus recuerdos-. ¡Álcese, pues, de su asiento la magnífica imagen creada por el pincel de Goya, y muéstrese!»» ${ }^{73}$.

Ya se ha hecho referencia al «palique»-«Preparativos del centenario», $M a-$ drid Cómico- que en 1892 Leopoldo Alas (Clarín) le dedicó a los fastos. La celebración se coronó con la edición de un folleto que recogía los actos del día de la inauguración. El «zar de Asturias», como llamaba Clarín al gran cacique Alejandro Pidal y Mon, leyó un texto -Glorias asturianas- en el que mezclaba a Jovino con los «tres nombres más celebres de la cultura española contemporánea Menéndez y Pelayo, Zeferino González y Campoamor». Hubo poesías en bable, gallego (Alfredo Braña), vasco (K. Echegaray), y catalán (J. Franquesa y Gomís), un discurso de J. Rubió y Ors que vindicaba el regionalismo de Jovellanos $^{74}$, y se interpretó una «Cantata a Jovellanos» compuesta para la efemérides por Emilio Arrieta, sobre letra de Plácido Jove y Hevia, vizconde de Campo Grande.

Más modesto pero revestido de gran emotividad fue el busto -obra de Zenobio Barrón- que en 1932 se colocó en el campo de la Atalaya de Puerto de Vega. Fue sufragado por el «Grupo Excursionista Jovellanos» de Gijón contando con el apoyo de peñas ciclistas locales, de los ayuntamientos de Navia y, desde Gijón, con el del Ateneo Obrero y La Prensa -desde su páginas, E. Robles Múñiz (Pachín de Melás) será el auténtico mentor de la iniciativa. El busto, señalaba, debiera convertir en «templo desde el que meditar los males pasados para evitar los futuros» ${ }^{75}$.

\section{Buscando un lugar de reposo: representaciones funerarias}

La profesora Elena de Lorenzo ha señalado como la historia de los monumentos funerarios consagrados a Jovino ha sido «la historia del desbaratamiento

\footnotetext{
${ }^{73}$ Somoza (1901), pp. 221-223.

${ }^{74}$ Inauguración de la estatua de Jovellanos. Imp. Torres y Cía. Gijón, 1891.

${ }^{75}$ Robles Muñiz (Pachín de Melás) [1932] (2006), pp. 32-36 y 63-77.
} 
de su últimas voluntades». En efecto, contraviniendo el sentir del gijonés, quien había abogado por las sepulturas fuera de los cementerios, y sus propias disposiciones testamentarias de 1795 -«si durase la bárbara y nociva costumbre de hacerle en las iglesias, vaya mi cuerpo a la parroquia; pero quiero que, si es posible, se obtenga licencia para un cementerio particular» y para un entierro «sin pompa ni publicidad»-, sus restos recibirán sepultura inicial en la parroquia de Santa Marina de Puerto de Vega.

Desde entonces aquellos sufrieron un incesante trasiego hasta su descanso definitivo en Los Remedios. El 24 de septiembre de 1814 fueron exhumados, siendo enterrados primero en un humilde nicho del cementerio junto a la iglesia y, en 1842, en el interior de la iglesia de San Pedro, en la llamada Capilla de las Ánimas, tras una función fúnebre y la colocación de la lápida cuyo epitafio redactaran Quintana y Gallego ${ }^{76}$. Todavía en 1869 , los restos del ilustrado estuvieron a punto de ser trasladados a Madrid. Un decreto de 31 de mayo de aquel año resucitaba la vieja idea de José I de erigir, siguiendo el modelo del Panteón francés, un panteón de hombres ilustres al que se pretendía incorporar los restos de 25 «grandes figuras nacionales» -el Cid, Guzmán el Bueno, Garcilaso, Calderón, Marina, Cisneros, Quevedo, Nebrija, Aranda, Jovellanos.... La resistencia del ayuntamiento de Gijón desbarató los planes del gobierno ${ }^{77}$.

En 1936, al incendiarse la citada iglesia de San Pedro, volvía a abrirse un nuevo debate sobre la ubicación definitiva de los restos ${ }^{78}$. Durante la Guerra Civil, la iglesia sufrió un incendio, y Emilio Robles Muñiz con la ayuda del alcalde anarquista Avelino González Mallada, recuperó la arqueta de plomo para trasladarla provisionalmente a la Escuela de Comercio. Allí permanecieron los restos hasta que de nuevo fue objeto de traslado, esta vez hasta el cercano Instituto Jovellanos, donde el arca quedó depositada unos meses. En 1940 reciben sepultura en la casa familiar, de donde son de nuevo removidos cuando se acomete el arreglo de la capilla de los Remedios, en la que volverá a descansar desde el 3 de febrero de 1978.

Además de las lápidas funerarias, Somoza inventarió las numerosas inscripciones redactadas por el ilustrado para grabar cartelas esculpidas con ocasión de la inauguración de obras públicas, para presidir instituciones docentes o religiosas, u ofrecidas para homenajear a la monarquía o a sus ministros. Recoge

${ }^{76}$ En la lápida provisional de Puerto de Vega, figuraba ésta inscripción: «Aquí yace un magistrado, honor de España y de Asturias, a quien la Parca y las Furias reduxeron a este estado. Fue perseguido, ultrajado del ignorante valido...»: Cfr. Somoza (1901), p. 225. Sobre los actos de 1842: "Traslación de las cenizas de Jovellanos el 20 de abril de 1842", en Inauguración de la estatua de Jovellanos (1891), cit.

${ }^{77}$ De Lorenzo (2011): pp. 296-299.

${ }^{78}$ Robles Muñiz (Pachín de Melas) [1936] (2006) -“Exhumación de los restos de Jovellanos”, La Prensa-, pp. 116-123. 
igualmente las numerosas placas conmemorativas que homenajean a Jovellanos. Llaman la atención las siete que lleva incorporadas la escribanía utilizada por Jovellanos en Mallorca y que fue trasladada a Madrid al celebrarse las capitulaciones matrimoniales entre Alfonso XII y María Cristina. Llevaba este texto: «La historia registrará como el hecho más glorioso del reinado de Alfonso XII la abolición de la esclavitud, y consignará que para la sanción de la ley libertadora se honró la memoria del Gran Jovellanos usándose esta escribanía».

\section{Jovellanos de mano en mano: filatelia, numismática, lotería}

En 1893 y 1898, el Banco de España promueve dos emisiones de billetes impresos en calcografía y tipografía con marcas de agua -de 25, 50 y 100 pesetas y con una tirada conjunta de 17 millones de unidades- con Jovellanos como motivo facial. Reproducen la cabeza del busto del gijonés que, labrado en mármol en 1887 por el escultor José Grajera y Herboso, se destinó al Palacio del Senado. La reproducción, advierte González Santos, guarda semejanza con la cabeza del monumento de Manuel Fuxá Leal, instalado en 1891 en la plaza del Seis de Agosto, y con la precedente del modelo para otro monumento de Sabino de Medina y Peñas (Madrid, 1812-1888), de hacia $1848^{79}$

En 1935, por orden ministerial de 11 de noviembre, la segunda República realizaba una emisión de sellos -de 5, 10, 15, 25, 30 y 50 céntimos de pesetadentro de una serie dedicada a honrar «personalidades destacadas de nuestra historia» -Blasco Ibáñez, Mariana Pineda, Concepción Arenal, M. Ruiz Zorrilla, G. de Azcárate, N. Salmerón y Jovellanos. En todos figuraba la leyenda «República española». La impresión calcográfica, a partir de un grabado de Camilo Delhom, partía del retrato del gijonés conservado en el Museo Lázaro Galdiano, atribuido hasta 1957 a Goya -si bien, no unánimemente- y, posteriormente, a Agustín Esteve primero y a Antonio Carnicero más tarde. Para González Santos se trata de una atribución errónea al considerarlo como un retrato anónimo de escuela española del primer tercio del siglo XIX. La estampa circuló en ambas zonas de España, republicana y nacional, y no perdió su valor de franqueo hasta el final de la guerra en la primera de las zonas, y hasta el 31 de julio de 1937 en la nacional. En 1938, una orden del ministerio de Hacienda fechada en Barcelona, autorizaba la circulación provisional de sellos-moneda o timbres móviles que podían ser utilizados como moneda fraccionaria -el sello se adhería a discos de cartón-. Por este medio, la citada emisión alcanzó renovada difusión.

En 1965 se produce una nueva emisión dedicada a personajes históricos Donoso Cortés, Alfonso X El Sabio, Santo Domingo de Guzmán y Jovellanos-. El del ilustrado asturiano, de valor de 2,50 pesetas tuvo una tirada de 4,5 millo-

${ }^{79}$ Cfr. González Santos (2012), pp. 60-71. 
nes de unidades. La imagen, según González Santos, es apócrifa, pues no responde a ningún retrato fidedigno de don Gaspar y fue «inventado por la Fábrica Nacional de Moneda y Timbre». El tercer sello, de 2002 -0,10 céntimos de euro, tirada de 1,2 millones de unidades- formaba parte de una serie que rememoraba acontecimientos históricos tratados de forma alegórica por los dibujantes Gallego y Rey. El dedicado a Jovellanos reproduce una jaula abierta de la que se escapa un libro alusivo a la fuerza de las ideas frente a la represión, el destierro o la cárcel. Una cuarta emisión de 2011, con ocasión del bicentenario de su muerte reproduce la cabeza del lienzo de Goya de1798. La misma serie -con valores de franqueo de 0,80 céntimos de euro y tirada de 300.000 unidadesreproducía a M. Servet, L. Rosales, M. Delibes y Vargas Llosa. Por último, en 1988, coincidiendo con el bicentenario de Carlos III, el Jovellanos de Goya de 1798, aparecía en los décimos de lotería acompañado de la siguiente leyenda: «Carlos III y la Ilustración. Jovellanos, gran polígrafo gijonés de talante liberal y espíritu reformador que se reflejó en sus discursos e informes sociales y económicos».

\section{CONCLUSIÓN: RESISTIENDO A LECTURAS Y LECTORES}

"[...] Jovellanos era ya entonces una piedra de toque,
pero aún más después del doble proceso de extorsión y
de falsificación a que ha sido sometido desde la sobre-
carga ideológica neoliberal y desde el españolismo de
la excluyente interpretación astur (sobre todo) caste-
llana del pensamiento español» (E. Lluch $\left.{ }^{80}\right)$.

En las dos últimas décadas, desde las diversas historias -la del pensamiento económico, la del constitucionalismo, la literaria...-, se han elaborado análisis científicos que pretenden ofrecer lecturas, sino definitivas -las palabras de Lluch son en este sentido elocuentes-, si objetivas y contrastables de la obra de Jovellanos. Pero como se decía al principio, el objeto de estas páginas no pretendía tanto la consideración de estas aproximaciones académicas, cuanto la exposición de aquellas otras lecturas alternativas y que han sido calificadas como «mundanas». A menudo, unas y otras se encuentran; con mayor frecuencia, se ignoran, $y$, en algunos casos, comparten «mercenariazgo».

Las visiones tópicas de Jovellanos -las más «populares» o las más «políticas», si es que cabe tal distinción-, no aspiran a contrastarse en el ámbito estricto, reducido y exclusivo de la ciencia, sino en el más amplio mercado de la política o de la sociología, de las pasiones y de los intereses. En un mercado tal, se ofertan visiones o arquetipos explicativos y simplificados que tratan de cubrir demandas bien concretas -cívicas, éticas, patrióticas, regionalistas...- en las que la utilidad la prima sobre la objetividad. En unos casos, aquellos tópicos satisfa-

${ }^{80}$ Cfr. Lluch (1999), p. 577. 
cen programas políticos que buscan en la historia de las ideas -en las de Jovellanos, en este caso- fuentes de legitimidad y de autoridad; en otros casos, los grupos sociales, -y no nos referimos únicamente al llamado «imaginario popular»encuentran en Jovellanos una bandera o un consuelo para afirmar esperanzas $u$ ocultar intereses.

Dicho esto, de ningún modo cabe pensar que el ámbito académico haya permanecido ajeno a esa confrontación de pasiones e intereses. El Jovellanos y el otoño de las luces, de Vicent Llombart, es buena prueba. Y en esa contienda, tampoco es fácil sustraerse a los tópicos. Tópicos como «revolución liberal»o «Antiguo Régimen» que, como reflexionaba Rosa Congost, están cargados de una fuerza interpretativa que prejuzga el desarrollo histórico y lo somete a leyes de necesidad capaces de consagrar el progreso a toda costa, incluso a costa de las personas ${ }^{81}$.

Jovellanos ha tenido mejor suerte iconográfica que literaria. Puede decirse que el Jovellanos de Goya, el retrato de 1798, posee más carga interpretativa y simbólica, más visibilidad y capacidad de convocatoria que miles de las referencias bibliográficas que componen el santoral jovellanista. Desde la república de las letras, Jovellanos no ha tenido quien le escriba. Y no será porque su trayectoria vital y sus «enigmas y certezas», no den para una biografía novelada de la altura de Azul cobalto, la hermosa biografía «posible» que Alfredo Conde dedicara al marqués de Sargadelos. Pero, aún así, y terminando con la misma cita de Vicent Llombart que encabezaba estas páginas, Jovellanos seguirá resistiendo lecturas y lectores.

\section{REFERENCIAS BIBLIOGRÁFICAS}

ALAS (“Clarín”), L. (2006): Obras completas, Edición de Y. Lissorgues. Oviedo: Nobel.

ALMENAR PALAU, S. (2002): "Economía política y liberalismo en España. De Jovellanos a la Gloriosa". En R. Robledo (ed.): Orígenes del liberalismo. Universidad, política, economía (pp. 81-104). Universidad de Salamanca,.

ÁLVAREZ BARRIENTOS, J. (2011): “1812. Isidoro de Antillón retrata a Jovellanos: moral y liberalismo para ciudadanos de bien". En Jovellanos, el valor de la razón (1811-2011) (pp. 631-649). Gijón: Instituto Feijoo de Estudios del Siglo XVIII/Trea.

ÁLVAREZ CASCOS, F. (1998): "Presentación". En Jovellanos. Ministro de Gracia y Justicia. Barcelona: Fundación La Caixa.

ÁLVAREZ CONDE, E. (1977): "El pensamiento político canovista", en Revista de Estudios Políticos, 213-214, pp. 233-295.

${ }^{81}$ Congost (2006), p. 70-77. 
ÁLVAREZ JUNCO, J. (1994): "La cultura republicana española a principios del siglo XX". En N. Townson (dir.): El republicanismo en España (1830-1877), (pp. 265-292). Madrid: Alianza Editorial.

ÁLVAREZ JUNCO, J. (2001): Mater Dolorosa. La idea de España en el siglo XIX. Madrid Taurus.

ÁLVAREZ SANTULLANO, L. (1936): Jovellanos. Estudio biográfico-crítico. Madrid: Biblioteca de la Cultura Española.

ÁLVAREZ-VALDÉS Y VALDÉS, M. (2012): Jovellanos: Vida y pensamiento. Oviedo: Nobel.

ANES ÁLVAREZ, G. (1994): "Cambio y actitudes conservadoras de Jovellanos", en Veintiuno Revista de pensamiento y cultura, Fundación Canovas, 23, pp. 65-74.

ANTILLÓN Y MARZO, I. (1812): Noticias históricas de don Gaspar Melchor de Jovellanos. Consagradas a sus respetables cenizas. Palma de Mallorca. (Reed. fac. de L. Esteban, Universidad de Valencia, 1994).

AZCÁRATE, G. DE (1880): “Jovellanos juzgado por un alemán”, en La Ilustración GaIlega y Asturiana, II (35).

BONET, J. A. (1944): Grandezas y desventuras de Don Gaspar Melchor de Jovellanos. Madrid: A. Aguado.

BONET, J. A. [1952]: Jovellanos, poema dramático en cuatro actos. (Reed. de J. Menéndez Peláez, Foro Jovellanos, Gijón, 2008).

CALVO MATURANA, A. (2011): "El héroe, el trasnochado y el mártir: tres imágenes de Jovellanos a ojos de sus contemporáneos". En Jovellanos, el valor de la razón (1811-2011). Gijón: Instituto Feijoo de Estudios del Siglo XVIII/ Trea, , pp. 651-665.

CASARIEGO, J. E. (1943): Jovellanos o el equilibrio. Ideas, desventuras y virtudes del inmortal hidalgo de Gijón. Madrid: Talleres Penitenciarios.

CASO GONZÁLEZ, J. M. (1978): “Un siglo de jovellanismo", en El Comercio, 27 de octubre, Gijón.

CASO GONZÁLEZ, J. M. (1988): "Una biografía inédita de Jovellanos: las Memorias de González Posada". En De Ilustración y de ilustrados. Oviedo: Instituto Feijoo de Estudios del Siglo XVIII, pp. 163-203.

CELA, J. (2003): "Jovellanos versus Francisco Ayala: dos hombres y una misma vocación de destino", en Espéculo. Revista de Estudios Literarios, Universidad Complutense.

CONGOST, Rosa (2006): Tierras, leyes, historia. Estudios sobre «la gran obra de la propiedad». Barcelona: Crítica.

DEROZIER, A. (ed.) (1969). Manuel José Quintana. Poesías completas. Madrid: Clásicos Castalia.

DÉROZIER, A. (1987): "Los orígenes del pensamiento liberal", en La época de la llustración. I. El Estado y la cultura (1759-1808),( pp.913-961), vol. XXXI (Historia de España: Menéndez Pidal). Madrid: Espasa-Calpe,.

DÍAZ, ELÍAS (2002): "El pensamiento social del krausismo español". En E. de Lorenzo Álvarez, A. Ruiz de la Peña Solar y A. Iravedra Valea (coords.): Leopoldo Alas: un clásico contemporáneo, (1901-2001) (pp. 44-66). Universidad de Oviedo.

ELIZALDE, I. (1995): "Jovellanos y su actitud sociopolítica”. En Estudios dieciochistas en homenaje al profesor J. Miguel Caso González, I, (pp. 261-295). Oviedo: Instituto Feijoo de Estudios del Siglo XVIII. 
FERNÁNDEZ CABEZÓN, R. (2011): "Composiciones poéticas dedicadas a Jovellanos". En Jovellanos, el valor de la razón (1811-2011) (pp. 667-682). Gijón: Instituto Feijoo de Estudios del Siglo XVIII/Trea.

FERNÁNDEZ CLEMENTE, E. (2001): "La propuesta del regeneracionismo español. Joaquín Costa". En E. Fuentes Quintana (dir.): Economía y economistas españoles. 5. Las críticas a la economía clásica (pp. 557-580). Barcelona: Círculo de Lectores.

FERNÁNDEZ SARASOLA, I. (2011): "La imagen del Jovellanos político en la historiografía”. En El pensamiento político de Jovellanos. Seis estudios, (pp. 215-249). Oviedo: In Itinere.

FLORIANO CUMBREÑO, A. C. (1944): Hispania. Tratado de educación patriótica. Madrid: Magisterio Español (4⿳亠丷⿵冂丶

FRAGA IRIBARNE, M. (1979): Jovellanos en la perspectiva de la sociedad española actual. Gijón: Ateneo Jovellanos.

FRAGA IRIBARNE, M. (1981): El pensamiento conservador español. Barcelona: Planeta.

GARCÍA CÁRCEL, R. (coord.) (2004): "Introducción" a La construcción de las historias de España (pp. 3-43). Madrid: M. Pons.

GARCÍA DE LEANIZ, I. (2012): "Desagravio y necesidad de Jovellanos", en Cuadernos de Pensamiento Político, Fundación FAES, abril-junio, pp. 233-240.

GIES, D. T. (1999): "Dos preguntas regeneracionistas: ¿Qué se debe a España? Y ¿Qué es España? Identidad nacional en Forner, Moratín, Jovellanos y la generación de 1898", en Dieciocho. Hispanic Enlightenment, vol. 22 (2), pp. 307-331.

GIL NOVALES. A. (1995): "Jovellanos en el siglo XIX: el problema de la revolución liberal", en Cuadernos de Estudios del Siglo XVIII, 5, pp. 101-125.

GÓMEZ OCHOA, F. (1995): El conservadurismo liberal y la Restauración. Tesis Doctoral. Santander: Universidad de Cantabria.

GONZÁLEZ SANTOS, J. (2012): Jovellanos y su entorno en las colecciones del Museo de Bellas Artes de Asturias. Oviedo: Museo de Bellas Artes de Asturias.

GONZÁLEZ SANTOS, J. (2011): "El monumento a Jovellanos en Oviedo". En Gaspar Melchor de Jovellanos (1722-1811). El monumento a Jovellanos en Oviedo, (pp. 312). Oviedo: Consejería de Cultura.

HERRERO, J. (1973): Los orígenes del pensamiento reaccionario español. Madrid: Edicusa.

LAVERDE RUIZ, G. (1868): “Jovellanos católico". En Ensayos críticos sobre filosofía, literatura e instrucción pública españolas. Lugo: Imp. S. Freire.

LISSORGES, Y. (2011): “El problema agrario en España: Leopoldo Alas, Clarín, y Adolfo Buylla en la estela de Jovellanos, o del optimismo de arriba a la dolorosa esperanza de abajo". En Jovellanos, el valor de la razón (1811-2011), (pp. 703-723). Gijón: Instituto Feijoo de Estudios del Siglo XVIII/ Trea.

LISSORGUES, Y. (2010): "Clarín y Jovellanos", Cuadernos Dieciochistas, 11, pp. 141152.

LLOMBART, V. (2013): “Jovellanos en la historia". En Jovellanos y el otoño de las Luces. Educación, economía, política y felicidad. Gijón: Ediciones Trea.

LLUCH, E. (1999): "El industrialismo en la Corona de Aragón y en la Corona de Castilla (siglo XVIII)". En E. Fuentes Quintana (dir.): Economía y economistas españoles. 3. La llustración (pp. 577-582). Barcelona: FUNCAS/Círculo de lectores. 
LORENZO ÁLVAREZ, E. DE (1999): “Visiones azorinianas de la Ilustración”, en Dieciocho. Hispanic Enlightenment, XXII, 1, pp. 87-110

LORENZO ÁLVAREZ, E. DE $\left(2011^{\mathrm{a}}\right)$ : "La construcción de un clásico". En J. Ocampo Suárez-Valdés (ed.): La Luz de Jovellanos (pp. 291-313). Madrid: Sociedad Estatal de Conmemoraciones Culturales, Ministerio de Cultura.

LORENZO ÁLVAREZ, E. DE (2011 ) : "Jovellanos divinizado. Los poemas laudatorios en alabanza del ministro (con un poema inédito de F. López Omaña)”. En Jovellanos, el valor de la razón (1811-2011) (pp. 723-739). Gijón: Instituto Feijoo de Estudios del Siglo XVIII/ Trea.

MALO DE GUILLÉN, J. L. (2001): "El pensamiento económico del krausismo español". En E. Fuentes Quintana (dir.): Economía y economistas españoles. 5. Las críticas a la economía clásica (pp. 389-450). Barcelona: Círculo de Lectores.

MARTÍNEZ RUIZ, J. (Azorín) (1913): "La decadencia de España”. En Clásicos y modernos. Buenos Aires: Losada (reed. 1959).

MENÉNDEZ UREÑA, E. (2001): "Krausismo y economía". En E. Fuentes Quintana (dir.): Economía y economistas españoles. 5. Las críticas a la economía clásica (pp. 297320). Barcelona: Círculo de Lectores

MENÉNDEZ Y PELAYO, M. (1882): "Vindicación de Jovellanos". En Historia de los heterodoxos españoles. Madrid: CSIC (red. 1947).

MORÁN BAYO, J. (1931): Hacia la revolución agraria española (Tres agraristas españoles: Jovellanos-F. Caballero-Costa). Córdoba: Imp. La Unión.

MORATINOS OTERO, O. Y V. CUETO FERNÁNDEZ (1998): Bibliografía jovellanista. Gijón: Fundación Foro Jovellanos.

NOCEDAL, C. (1865): Vida de Jovellanos. Madrid: Rivadeneyra.

NOCEDAL, C. (1858-1859): Obras publicadas e inéditas de D. Gaspar Melchor de Jovellanos, BAE, tomos XLVI (I) y L(II). Madrid: Rivadeneyra, Madrid (reed. Atlas, 1952 y 1963).

PÉREZ GALDÓS, B. (1873): La corte de Carlos IV. Madrid: T. Hernando (reed 1929.

PIÑER, LUIS A. (1936): Jovellanos. Discurso en el Instituto, 1936. Gijón: Ayuntamiento de Gijón (red. 2010).

PIQUERAS ARENAS, J. A. (2008): Cánovas y la derecha española. Barcelona: Península.

PONCELA, J. (2010): La aventura botánica de Jovellanos, Ayuntamiento de Gijón.

POZUELO ANDRÉS, Y. (2012): La masonería en Asturias (1931-1939). Oviedo: Universidad de Oviedo.

RíO, Ángel del (1935): "Introducción y notas". En Jovellanos. Obras escogidas. Madrid: Espasa-Calpe.

ROBLEDO HERNÁNDEZ. R. (1993): Economistas y reformadores españoles. La cuestión agraria (1760-1935). Madrid: Ministerio de Agricultura.

ROBLES MUÑIZ, E. (Pachín de Melás) (1932): Minucias transcendentales en torno a Jovellanos (Homenaje al Ateneo Obrero de Gijón, 1887-2006). Gijón: Fundación Foro Jovellanos (red. 2006).

RUBIO CREMADES, E. (1993): Azorín y Jovellanos, en Anales azorinianos, 5, pp. $237-$ 244.

RUIZ BERRIO, J. (1993): "Francisco Giner de los Ríos (1839-1915)”, en Perspectivas. Revista de educación Comparada, vol. XXIII (3-4), pp. 808-821. 
RUIZ MANJÓN, O. (2002): "La cultura política del republicanismo español”. En G. Gómez Ferrer (coord.): La época de la Restauración (1875-1902) (pp. 178-196): Historia de España. Menéndez Pidal, XXXVI, II. Madrid: Espasa- Calpe.

SAN JOSÉ, E. (2012): "El proceso contra el padre Mier: su recurso ante Jovellanos". En Jovellanos, el valor de la razón (1811-2011) (pp. 413-424). Gijón: Instituto Feijoo de Estudios del Siglo XVIII/ Trea.

SÁNCHEZ COLLANTES, S. (2011): "La faceta jovellanista del republicanismo español". En Jovellanos, el valor de la razón (1811-2011), (pp. 753-771). Gijón: Instituto Feijoo de Estudios del Siglo XVIII/ Trea.

SÁNCHEZ CORREDERA, S. (2004): Jovellanos y el jovellanismo. Una perspectiva filosófica. Oviedo: Ediciones Pentalfa.

SECO SERRANO, C. (1982): "Fraga y la tradición conservadora española”, Cuenta y Razón, núm. 6 (primavera).

SERRANO SANZ, J. M. (1997): "Los estudios económicos en España a finales del siglo XIX: historia de un estancamiento". En G. Bel y A. Estruch (coords.), Industrialización en España. Entusiasmos, desencantos y rechazos (Ensayos en homenaje al profesor Fabián Estapé) (pp. 249-267). Madrid: Civitas.

SILVA CIENFUEGOS-JOVELLANOS, P. DE (1995): “¿Un Jovellanos federalista?”. En Estudios dieciochistas en homenaje al profesor J. Miguel Caso González, (II, pp. 329-337). Oviedo: Instituto Feijoo de Estudios del Siglo XVIII, 2 vols.

SOLDEVILLA, F. (1887): Jovellanos. Sus obras y su tiempo. París: Lib. Garnier.

SOMOZA, J. (1901): Inventario de un jovellanista. Madrid: Tip. Sucesores de Rivadeneyra.

SOMOZA, J. (1931): "Prólogo". En V. Huici Miranda (ed.), Jovellanos. Miscelánea de trabajos inéditos, varios y dispersos. Gijón: Rotary Club.

VELA, FERNANDO (1915): "Un día en la vida de Jovellanos". En El grano de pimienta. Argentina: Austral (red. 1950). 
